\title{
EKSPLORASI POTENSI EKSTRAK CAIR DAUN KECOMBRANG YANG MENGANDUNG ANTIOKSIDAN SEBAGAI PENETRALISIR RADIKAL BEBAS DALAM DARAH PETUGAS SPBU
}

\author{
Azzah Farah Fadiyah*, Resi Mukti Wardhani, Nurmei Rahmatika, Siwi Pramatama Mars Wijayanti \\ Universitas Jenderal Soedirman \\ Jalan dr. Soeparno Karangwangkal Purwokerto 53122 \\ Korespondensi: azzahfarahfadiyah@gmail.com
}

\begin{abstract}
Employment as an officer of Gas Station (SPBU) has risks from exposure to free radicals in the gas station environment which can cause lipid, DNA, and protein modifications to various body tissues. To neutralize these free radicals the body has a natural antioxidant that is Superoxide Dismutase (SOD). Leaf kecombrang has antioxidant content, especially flavonoids that can neutralize free radicals. Therefore, it aims to explore the potential of liquid extract of kecombrang leaves as the neutralizing of free radicals in the blood. This research method is an experimental research that is tested in mice. Steps taken in this study include the making of leaf extract kecombrang, treatment of animal testing and analysis SOD blood serum. Wistar strains of 16 male mice were divided into 4 groups, that was positif group control which induce CCL4 $1 \mathrm{~mL} / \mathrm{KgBB}$ and $1 \% \mathrm{NaC} \mathrm{CMC}$ as placebo, 1st treatment group which induced $1 \mathrm{~mL} / \mathrm{KgBB}$ CCL4 and leaf extract of $100 \mathrm{mg} / \mathrm{KgBB}$, 2nd treatment group which induced $1 \mathrm{~mL} / \mathrm{KgBB}$ CCL4 and 150mg / KgBB leaf extracts, 3rd treatment group which induced $1 \mathrm{~mL} / \mathrm{KgBB} \mathrm{CCL} 4$ and 200mg / KgBB leaf root extract. Each group consists of 4 rats. Based on the results of experiments measurements of SOD levels found that the extract of leaves kecombrang can increase blood serum SOD levels of rats induced CCL4 as free radicals. Based on experimental results also known that optimal dose of liquid extract of leaf of kecombrang to increase blood serum SOD level in research subject is $150 \mathrm{mg} / \mathrm{KgBB}$. From this research it is known that there is potential to develop liquid extract of leaf of kecombrang as free radical neutralization.
\end{abstract}

Keywords: Kecombrang leaf liquid extract, free radicals, antioxidants, SOD, In Vivo

\begin{abstract}
ABSTRAK
Pekerjaan sebagai petugas Stasiun Pengisian Bahan Bakar Umum (SPBU) memiliki risiko akibat paparan radikal bebas di lingkungan SPBU yang dapat menyebabkan modifikasi lipid, DNA, dan protein pada berbagai jaringan tubuh. Untuk menetralisir radikal bebas tersebut tubuh memiliki antioksidan alami yaitu Superoksida Dismutase (SOD). Daun kecombrang memiliki kandungan antioksidan terutama flavonoid yang mampu menetralisir radikal bebas. Oleh karena itu, bertujuan mengeksplorasi potensi ekstrak cair daun kecombrang sebagai penetralisir radikal bebas dalam darah. Metode penelitian ini merupakan penelitian eksperimen yang diujikan pada tikus. Langkah yang dilakukan dalam penelitian ini antara lain pembuatan ekstrak daun kecombrang, perlakuan terhadap hewan uji dan pemeriksaan kadar SOD serum darah hewan uji. Hewan uji berupa tikus jantan galur Wistar sebanyak 16 ekor yang dibagi menjadi 4 kelompok, yaitu kelompok kontrol positif yang diinduksi $\mathrm{CCL}_{4} 1 \mathrm{~mL} / \mathrm{KgBB}$ dan placebo berupa Na-CMC 1\%, kelompok perlakuan 1 yang diinduksi $\mathrm{CCL}_{4} 1 \mathrm{~mL} / \mathrm{KgBB}$ dan ekstrak daun kecombrang $100 \mathrm{mg} / \mathrm{KgBB}$, kelompok perlakuan 2 yang diinduksi $\mathrm{CCL}_{4} 1 \mathrm{~mL} / \mathrm{KgBB}$ dan ekstrak daun kecombrang $150 \mathrm{mg} / \mathrm{KgBB}$, dan kelompok perlakuan 3 yang diinduksi $\mathrm{CCL}_{4} 1 \mathrm{~mL} / \mathrm{KgBB}$ dan ekstrak daun kecombrang $200 \mathrm{mg} / \mathrm{KgBB}$. Masing-masing kelompok terdiri dari 4 ekor tikus. Berdasarkan hasil eksperimen pengukuran kadar SOD didapati hasil bahwa ekstrak daun kecombrang dapat meningkatkan kadar SOD serum darah tikus yang diinduksikan CCL4 sebagai radikal bebas. Berdasarkan hasil eksperimen juga diketahui bahwa dosis optimal ekstrak cair daun kecombrang untuk meningkatkan kadar SOD serum darah pada subjek penelitian adalah $150 \mathrm{mg} / \mathrm{KgBB}$. Dari penelitian ini diketahui bahwa ada potensi untuk mengembangkan ekstrak cair daun kecombrang sebagai penetralisisr radikal bebas.
\end{abstract}

Kata Kunci: Ekstrak cair daun kecombrang, Radikal bebas, Antioksidan, SOD, In Vivo 


\section{PENDAHULUAN}

Setiap pekerjaan memiliki risiko dan bahaya kerja masing-masing, mulai dari tingkat kecil, sedang, hingga besar. Salah satu pekerjaan yang memiliki risiko dan bahaya besar adalah petugas Stasiun Pengisian Bahan Bakar Umum (SPBU). Pekerjaan tersebut memiliki risiko kerja besar dikarenakan kemungkinan dampak negatif yang disebabkan paparan senyawa eksogen dalam tubuh yang dapat menjadi radikal bebas. Radikal bebas merupakan salah satu bentuk senyawa oksigen reaktif dan biasanya diketahui sebagai senyawa yang memiliki elektron yang tidak berpasangan (Winarsi, 2007). Elektron yang tidak berpasangan pada orbit terluar suatu senyawa dapat mengakibatkan senyawa tersebut menjadi radikal bebas yang sangat reaktif dan tidak stabil. Oleh karena itu, senyawa tersebut bereaksi dengan senyawa disekelilingnya sehingga mendapatkan pasangan elektron dan mencapai bentuk kestabilan menjadi non-radikal yang tidak reaktif. Reaksi radikal bebas yang terjadi secara terus menerus dalam tubuh dapat menimbulkan berbagai penyakit karena dapat mengoksidasi beberapa makromolekul tubuh seperti protein, asam nukleat dan lipid (Kurnia dan Taufikurohmah, 2017; Murray, 2009). Senyawa oksigen reaktif dapat meningkatkan modifikasi lipid, DNA, dan protein pada berbagai jaringan sehingga menyebabkan kerusakan berbagai jaringan (Lavi, et al., 2008).

Peningkatan radikal bebas dalam tubuh dapat disebabkan oleh senyawa eksogen. Contoh senyawa eksogen yang dapat meningkatkan oksidan dalam tubuh antara lain emisi gas buangan kendaraan bermotor seperti timbal, karbon dioksida, uap bensin dan karbon monoksida yang banyak terdapat di lingkungan SPBU. Uap bensin mengandug toluen, benzena, xylene atau hidrokarbon aromatik polisiklik (PAH). Senyawa-senyawa tersebut akan dimetabolisme oleh tubuh dan menghasilkan radikal bebas seperti radikal hidroksil dan anion superoksida (Safyudin dan Subandrate, 2015).

Secara normal, di dalam tubuh sudah terdapat radikal bebas. Tubuh memiliki antioksidan alami yang bekerja menghambat oksidasi dengan cara bereaksi dengan radikal bebas reaktif membentuk radikal bebas yang lebih stabil. Antioksidan alami dalam tubuh antara lain Superoksida dismutase (SOD) yang merupakan antioksidan intaseluler, dan antosianin yang merupakan turunan dari flavonoid sebagai antioksidan ekstraseluler. Namun, radikal bebas yang telalu banyak dapat menyebabkan antioksidan alami tersebut tidak dapat mengatasinya dan menyebabkan terjadinya kondisi stres oksidatif. Oleh karena itu, tubuh memerlukan asupan antioksidan dari luar (Herdiani, dkk., 2015).

Berbagai bahan alami bisa dimanfatkan sebagai antioksidan untuk menetralisir radikal bebas, salah satunya adalah daun dari tanaman kecombrang. Ekstrak dari daun kecombrang ini memiliki tingkat antioksidan yang tinggi sebesar $1 \mathrm{C}_{50} \quad 52,05(\mu \mathrm{g} / \mathrm{mL})$ untuk setiap 0,996 $\mathrm{r}^{2}$ (Kusriani, dkk., 2017). Terdapat berbagai antioksidan dalam ekstrak daun kecombrang, salah satunya adalah flavonoid yang dapat mengikat radikal bebas. Oleh karena itu, penelitian ini bertujuan untuk mengetahui potensi ekstrak cair daun kecombrang dalam menetrasir radikal bebas dalam darah.

\section{RUMUSAN MASALAH}

Terdapat banyak sekali SPBU di Indonesia dengan jumlah pekerja yang banyak pula. Pekerja tersebut memiliki risiko besar terpapar radikal bebas yang ada di lingkungan SPBU. Dampak negatif dari paparan radikal bebas untuk kesehatan belum dapat terlihat secara langsung. Hal itu terjadi karena radikal bebas memiliki antioksidan alami dalam tubuh. Namun paparan radikal bebas yang berlebihan menyebabkan antioksidan alami 
tidak dapat menangani radikal bebas tersebut. Radikal bebas yang berlebihan dalam tubuh dapat menyebabkan modifikasi lipid, DNA, dan protein pada berbagai jaringan sehingga menyebabkan kerusakan berbagai jaringan karena radikal bebas dapat mengoksidasi beberapa makromolekul tubuh seperti protein, asam nukleat dan lipid (Murray, 2009).

Tanaman kecombrang terbukti memiliki kadar antioksidan yang tinggi sehingga dapat dimanfaatkan sebagai penangkal radikal bebas. Bagian daun kecombrang terbukti memiliki kadar antioksidan tertinggi (Kusriani, dkk., 2017). Menurut penelitian Ahmad, dkk., (2017), menyebutkan bahwa kandungan senyawa flavonoid ekstrak daun kecombrang sebesar 5,45\% b/b dihitung terhadap kuersetin. Kandungan tersebut, bila mampu mengikat radikal bebas yang terpapar petugas SPBU setiap harinya, dapat dimanfaatkan sebagai zat aktif penetralisir radikal bebas dalam tubuh. Maka rumusan masalah yang diangkat dalam penelitian ini adalah apakah ekstrak cair daun kecombrang dapat dimanfaatkan sebagai zat aktif penetralisir radikal bebas dalam darah petugas SPBU?

\section{TINJAUAN PUSTAKA}

\subsection{Kecombrang}

Kecombrang termasuk ke dalam famili Zingiberaseae yang bereproduksi dengan tunas dan rimpang. Kecombrang merupakan tanaman tropis tahunan yang tumbuh merumpun dengan susunan yang tidak terlalu rapat. Bunga kecombrang berwarna merah tumbuh tegak di atas batang yang panjangnya $0,8-2,2$ meter. Setelah berusia dua tahun, kecombrang akan berbunga dan berbuah (Lestari dan Ira, 2008).Selain digunakan sebagai bumbu tambahan pada makanan, kecombrang juga banyak dimanfaatkan sebagai obat karena kandungan bioaktifnya yang cukup banyak, antara lain karbohidrat, serat pangan, lemak, protein, air, zat besi, kalsium dan magnesium.

Menurut Kurniawan, dkk (2017), semua tanaman berpembuluh mengandung flavonoid yang berfungsi sebagai pengatur tumbuh, pengatur fotosintesis, kerja anti mikroba dan antivirus. Selain itu, kecombrang tersusun dari flavonoid, polifenol, steroid, saponin, minyak atsiri dan alkaloid sehingga kecombrang dapat digunakan sebagai sumber antioksidan bagi manusia (Kartika, dkk., 2017). Antioksidan sendiri merupakan senyawa yang dibutuhkan oleh tubuh untuk menetalisir dan mencegah kerusakan yang ditimbulkan oleh radikal bebas terhadap sel normal, protein dan lemak. Senyawa antioksidan yang dapat menetralisir radikal bebas utamanya adalah flavonoid.

\subsection{Radikal Bebas}

Radikal bebas adalah suatu molekul yang mempunyai satu atau lebih elektron yang tidak berpasangan atau elektron bebas di orbit luarnya sehingga bersifat tidak stabil. Radikal bebas sangat reaktif mencari pasangan elektronnya sebagai upaya untuk mencapai kestabilannya sehingga disebut juga reactive oxygen species (ROS). Mekanisme mencari pasangan elektron dapat dilakukan dengan donasi, meski umumnya dengan mencuri dari molekul bagian tubuh yang lain (Ardhie, 2011). Molekul yang kehilangan elektron ini dapat menjadi bersifat reaktif, terutama asam lemak tak jenuh yang kemudian berubah menjadi radikal bebas yang sangat reaktif (Astuti, 2008).

Radikal bebas dapat terbentuk secara alamiah oleh tubuh dan juga dapat terbentuk dari lingkungan. Radikal bebas dapat terbentuk secara alamiah oleh tubuh 
melalui reaksi inflamasi, respirasi di mitokondria, dan kelebihan gizi karena saat dimetabolisme tidak hanya energi yang akan dihasilkan tetapi juga akan menghasilkan radikal bebas. Radikal bebas yang terbentuk dari lingkungan antara lain sinar ultraviolet matahari antara pukul 10.00-15.00, polusi asap rokok dan pabrik, emisi kendaraan bermotor serta konsumsi minuman beralkohol (Ardhie, 2011). Keadaan tingginya kadar radikal bebas dalam tubuh dapat menyebabkan stress oksidatif. Stress oksidatif adalah keadaan tidak seimbang antara radikal bebas dan antioksidan yang dipicu oleh dua kondisi umum yakni kurangnya antioksidan dan kelebihan produksi radikal bebas. Dampak dari tingginya kadar radikal bebas antara lain dapat menyebabkan penyakit stroke, asma, diabetes melitus, radang usus, penyumbatan kronis pembuluh darah di jantung, penyakit Parkinson, dan lainnya (Ardhie, 2011).

\subsection{Superoksida Dismutase (SOD)}

Antioksidan merupakan senyawa pertahanan biologi terhadap oskidan atau radikal bebas. Antioksidan yang secara alami diproduksi di dalam tubuh berupa tiga enzim yaitu Superoksida dismutase (SOD), glutation peroksidase (GSH Px), dan katalase (Wresdiyati, 2003). Di antara antioksidan paling kuat yang mampu memperbaiki efek stress oksidatif adalah enzim superoxide dismutase atau superoksida dismutase. Enzim SOD mengkatalis perubahan superoksida menjadi hidrogen peroksida dan oksigen, dimana superoksida merupakan suatu radikal yang bersifat sangat reaktif (Nurhayati dkk, 2011). Superoksida dismutase (SOD) merupakan sistem pertahanan alami yang dimiliki oleh tubuh terhadap radikal bebas (Astuti, 2008).

\section{METODE PENELITIAN}

Jenis penelitian ini yaitu eksperimental laboratorium. Tahap in vivo yang digunakan adalah True Experimental Laboratory dengan post test only control group design.

Bahan yang digunakan untuk penelitian ini adalah daun kecombrang yang diekstrasi dengan metanol p.a. kemudian dilarutkan dengan Na-CMC 1\%. Untuk penginduksi radikal bebas digunakan CCL4 yang dilarutkan dengan minyak zaitun. Bahan kimia yang digunakan untuk penetapan kadar SOD adalah buffer, $1000 \mu \mathrm{L}$ larutan buffer, $100 \mu \mathrm{L}$ xantin oksidase, dan $20 \mu \mathrm{L}$ larutan CAL sebagai larutan standar. Hewan uji yang digunakan adalah tikus jantan galur Wistar usia 3 bulan dengan berat badan $200-300$ gram yang diperoleh dari peternakan tikus di Solo.

\section{TAHAPAN ANALISIS}

\subsection{Pembuatan Ekstrak Daun Kecombrang}

Daun kecombrang sebanyak 150 g dilakukan sortasi basah dan pencucian untuk menghilangkan tanah dan pengotor lainnya yang masih menempel pada sampel. Ekstraksi daun kecombrang dilakukan dengan metode maserasi menggunakan pelarut metanol. Daun kecombrang dimaserasi lalu dilarutkan dengan metanol $450 \mathrm{~mL}$ di dalam botol kaca ukuran besar. Selanjutnya botol kaca ditutup dan didiamkan selama $2 \times 24$ jam terlindung dari cahaya matahari sambil sesekali diaduk, lalu disaring sehingga didapat maserat. Maserat lalu diuapkan menggunakan alat Rotary Vacuum Evaporator pada suhu $45^{\circ} \mathrm{C}$ hingga diperoleh ekstrak pekat daun kecombrang. 


\subsection{Perlakuan Terhadap Hewan Uji}

Hewan uji terdiri atas 16 ekor tikus jantan dipilih dengan cara random sampling dibagi menjadi 4 kelompok yaitu kelompok kontrol positif dan tiga kelompok perlakuan. Setiap kelompok terdiri dari 4 ekor tikus, sebagai berikut:

a) Kelompok 1 : kelompok kontrol positif yang diinduksi $\mathrm{CCL}_{4} 1 \mathrm{~mL} / \mathrm{KgBB}$ dan placebo berupa Na-CMC 1\%

b) Kelompok 2 : kelompok perlakuan 1 yaitu sampel yang diinduksi $\mathrm{CCL}_{4} 1$ $\mathrm{mL} / \mathrm{KgBB}$ dan ekstrak daun kecombrang $100 \mathrm{mg} / \mathrm{KgBB}$

c) Kelompok 3 : kelompok perlakuan 2 yaitu sampel yang diinduksi $\mathrm{CCL}_{4} 1$ $\mathrm{mL} / \mathrm{KgBB}$ dan ekstrak daun kecombrang $150 \mathrm{mg} / \mathrm{KgBB}$

d) Kelompok 4 : kelompok perlakuan 3 yaitu sampel yang diinduksi $\mathrm{CCL}_{4} 1$ $\mathrm{mL} / \mathrm{KgBB}$ dan ekstrak daun kecombrang $200 \mathrm{mg} / \mathrm{KgBB}$

Tahap in vivo dilakukan dengan memberikan CCL4 dan esktran daun kecombrang sesuai dosis yang telah ditentukan. Perlakuan tersebut dilakukan slama 4 hari. Pada tahap akhir dilakukan pengambilan darah tikus melalui vena mata dan dilakukan pengujian kadar SOD serum. Pembacaan hasil uji SOD dilakukan pada Spektro UV-Vis.

Pada tahap awal dilakukan analisis normalitas dengan uji Kolmogorofsmirnof dan uji homogenitas dengan metode SPSS. Apabila didapatkan data normal dan homogen, maka selanjutnya dilakukan analisis perbandingan antar kelompok dengan uji One Way Anova. Apabila ada perbedaan yang signifikan, maka pengujian dilanjutkan dengan uji LSD untuk mengetahui dosis ekstrak daun kecombrang yang lebih efektif dalam menaikkan kadar SOD serum darah tikus dengan kepercayaan $\alpha=5 \%$.

\section{HASIL DAN PEMBAHASAN}

\subsection{Hasil}

Berdasarkan hasil penelitian, telah didapatkan kadar SOD serum hewan uji. Hasil analisis rata-rata kadar SOD serum disajikan pada Gambar 1 di bawah.

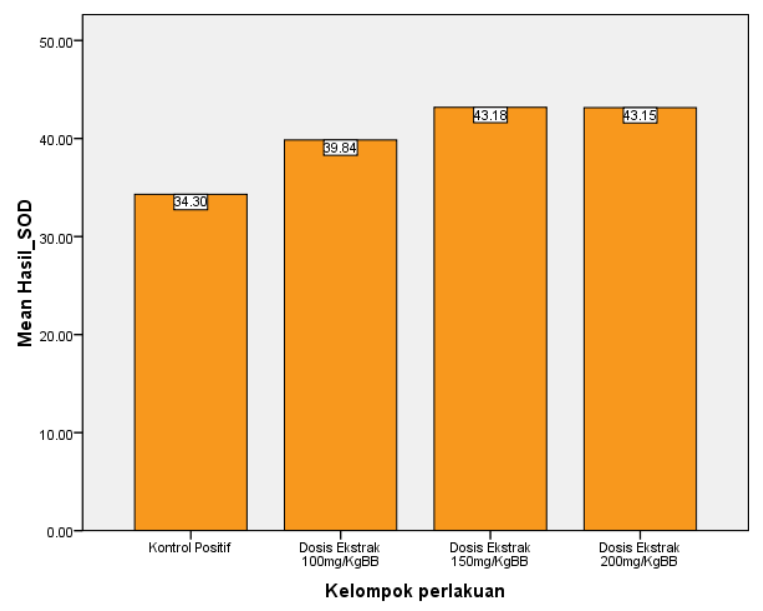

Gambar 1 Rata-rata SOD Serum Berdasarkan Kelompok

Berdasarkan Gambar 1. diketahui bahwa rata-rata kadar SOD kelompok yang diberikan ekstrak cair daun kecombrang dengan dosis $200 \mathrm{mg} / \mathrm{KgBB}$ yaitu 43,1500 U/ml. Rata-rata kadar SOD kelompok yang diberi ekstrak cair daun kecombrang dengan dosis $150 \mathrm{mg} / \mathrm{KgBB}$ yaitu 43,1850 U/ml. Rata-rata kadar SOD kelompok 
yang diberi ekstrak cair daun kecombrang dengan dosis $100 \mathrm{mg} / \mathrm{KgBB}$ yaitu 39,8425 U/ml. Rata-rata kadar SOD kelompok kontrol positif yaitu 34, $3000 \mathrm{U} / \mathrm{ml}$. Kadar SOD serum yang paling tinggi pada kelompok yang diberi esktak cair daun kecombrang dengan dosis $150 \mathrm{mg} / \mathrm{KgBB}$ dan pada kelompok yang diberi esktrak cair daun kecombrang dengan dosis $200 \mathrm{mg} / \mathrm{KgBB}$, masing-masing rata-rata kadar SODnya adalah 43,1850 dan 43,1500. Kadar SOD paling rendah yaitu pada kelompok kontrol positif dengan rata-rata kadar SOD-nya 34,3000.

Hasil uji statistik dengan Anova menunjukan bahwa jenis perlakuan pada uji in vivo memberikan pengaruh nyata $(\alpha=0,05)$ terhadap kadar SOD sehingga perlu dilakukan uji lanjut LSD untuk melihat kelompok perlakuan mana yang paling efektif dalam menaikkan kadar SOD. Table 1 dibawah ini menujukan hasil uji LSD.

Table 1 Hasil uji LSD

\section{Multiple Comparisons}

Hasil_SOD

LSD

\begin{tabular}{|c|c|c|c|c|c|c|}
\hline \multirow{2}{*}{$\begin{array}{l}\text { (I) Kelompok } \\
\text { perlakuan }\end{array}$} & \multirow{2}{*}{$\begin{array}{l}\text { (J) Kelompok } \\
\text { perlakuan }\end{array}$} & \multirow{2}{*}{$\begin{array}{c}\text { Mean } \\
\text { Difference } \\
(\mathrm{I}-\mathrm{J})\end{array}$} & \multirow{2}{*}{$\begin{array}{l}\text { Std. } \\
\text { Error }\end{array}$} & \multirow[b]{2}{*}{ Sig. } & \multicolumn{2}{|c|}{$95 \%$ Confidence Interval } \\
\hline & & & & & $\begin{array}{l}\text { Lower } \\
\text { Bound }\end{array}$ & $\begin{array}{l}\text { Upper } \\
\text { Bound }\end{array}$ \\
\hline \multirow[t]{3}{*}{ Kontrol Positif } & $\begin{array}{l}\text { Dosis Ekstrak } \\
100 \mathrm{mg} / \mathrm{KgBB}\end{array}$ & $-5.54250^{*}$ & 1.14667 & .000 & -8.0409 & -3.0441 \\
\hline & \begin{tabular}{|l|} 
Dosis Ekstrak \\
$150 \mathrm{mg} / \mathrm{KgBB}$ \\
\end{tabular} & $-8.88500^{*}$ & 1.14667 & .000 & -11.3834 & -6.3866 \\
\hline & \begin{tabular}{|l|} 
Dosis Ekstrak \\
$200 \mathrm{mg} / \mathrm{KgBB}$
\end{tabular} & $-8.85000^{*}$ & 1.14667 & .000 & -11.3484 & -6.3516 \\
\hline \multirow{3}{*}{$\begin{array}{l}\text { Dosis Ekstrak } \\
100 \mathrm{mg} / \mathrm{KgBB}\end{array}$} & Kontrol Positif & $5.54250^{*}$ & 1.14667 & .000 & 3.0441 & 8.0409 \\
\hline & \begin{tabular}{|l|} 
Dosis Ekstrak \\
$150 \mathrm{mg} / \mathrm{KgBB}$
\end{tabular} & $-3.34250^{*}$ & 1.14667 & .013 & -5.8409 & -.8441 \\
\hline & \begin{tabular}{|l|} 
Dosis Ekstrak \\
$200 \mathrm{mg} / \mathrm{KgBB}$
\end{tabular} & $-3.30750^{*}$ & 1.14667 & .014 & -5.8059 & -.8091 \\
\hline \multirow{3}{*}{$\begin{array}{l}\text { Dosis Ekstrak } \\
150 \mathrm{mg} / \mathrm{KgBB}\end{array}$} & Kontrol Positif & $8.88500^{*}$ & 1.14667 & .000 & 6.3866 & 11.3834 \\
\hline & $\begin{array}{l}\text { Dosis Ekstrak } \\
100 \mathrm{mg} / \mathrm{KgBB} \\
\end{array}$ & $3.34250^{*}$ & 1.14667 & .013 & .8441 & 5.8409 \\
\hline & $\begin{array}{l}\text { Dosis Ekstrak } \\
200 \mathrm{mg} / \mathrm{KgBB}\end{array}$ & .03500 & 1.14667 & .976 & -2.4634 & 2.5334 \\
\hline \multirow{3}{*}{$\begin{array}{l}\text { Dosis Ekstrak } \\
200 \mathrm{mg} / \mathrm{KgBB}\end{array}$} & Kontrol Positif & $8.85000^{*}$ & 1.14667 & .000 & 6.3516 & 11.3484 \\
\hline & $\begin{array}{l}\text { Dosis Ekstrak } \\
100 \mathrm{mg} / \text { KgBB } \\
\end{array}$ & $3.30750^{*}$ & 1.14667 & .014 & .8091 & 5.8059 \\
\hline & $\begin{array}{l}\text { Dosis Ekstrak } \\
150 \mathrm{mg} / \mathrm{KgBB}\end{array}$ & -.03500 & 1.14667 & .976 & -2.5334 & 2.4634 \\
\hline
\end{tabular}

*. The mean difference is significant at the 0.05 level.

Hasil uji LSD kadar SOD serum menujukan bahwa kadar SOD serum pada kelompok yang diberi ekstrak cair daun kecombrang dengan dosis $150 \mathrm{mg} / \mathrm{KgBB}$ tidak berbeda nyata dengan kelompok yang diberi ekstrak cair daun kecombrang dengan dosis $200 \mathrm{mg} / \mathrm{KgBB}$ dimana nilai Mean Difference $=0.03500$ (Mean Difference $<0,05$ ) saat kelompok tersebut dibandingkan. Kadar SOD kelompok yang 
diberi esktrak cair daun kecombrang dengan dosis $150 \mathrm{mg} / \mathrm{KgBB}$ berbeda nyata dengan kelompok kontrol positif, dimana Mean Difference $=8.8850$ (Mean Difference $>0,05$ ) saat kelompok tersebut dibandingkan. Kadar SOD kelompok yang diberi ekstrak cair daun kecombrang dengan dosis $150 \mathrm{mg} / \mathrm{KgBB}$ berbeda nyata dengan kelompok yang diberi ekstrak cair daun kecombrang dengan dosis 100 $\mathrm{mg} / \mathrm{KgBB}$, dimana Mean Difference $=3,34250$ (Mean Difference $>0,05$ ) saat kelompok tersebut dibandingkan. Kadar SOD kelompok yang diberi ekstrak cair daun kecombrang dengan dosis $100 \mathrm{mg} / \mathrm{KgBB}$ menunjukan perbedaan yang nyata dengan kelompok kontrol positif, dimana Mean Difference $=5.54250$ (Mean Difference $>0,05$ ) saat kelompok tersebut dibandingkan.

\subsection{Pembahasan}

Antioksidan yang secara alami diproduksi di dalam tubuh berupa tiga enzim yaitu Superoksida dismutase (SOD), glutation peroksidase (GSH Px), dan katalase (Wresdiyati, 2003). Di antara antioksidan paling kuat yang mampu memperbaiki efek stress oksidatif adalah enzim superoxide dismutase atau superoksida dismutase (Nurhayati dkk, 2011). Meski demikian, tubuh memerlukan asupan antioksidan tambahan untuk menjaga kadar SOD cukup untuk menangani radikal bebas yang masuk ke tubuh.

Berdasarkan hasil pemeriksan kadar SOD serum darah pada penelitian ini diketahui bahwa kelompok perlakuan 3 dan 4 lebih tinggi dari pada kelompok lain, dengan rata-rata kadar SOD pada masing-masing kelompok berturut-turut adalah 43,18 U/mL dan 43,15 U/mL. Hal ini dikarenakan kelompok tersebut sudah mendapatkan antioksidan tambahan dari ekstrak daun kecombrang sehingga kadar SOD meningkat setelah diinduksi radikal bebas.

Kadar SOD paling rendah adalah pada kelompok kontrol positif, yaitu 34,3 $\mathrm{U} / \mathrm{mL}$, diikuti tendensi peningkatan kadar SOD pada kelompok perlakuan seiring dengan peningkatan dosis yang diberikan. Peningkatan dosis berbanding lurus dengan peningkatan kadar SOD serum darah tikus. kelompok kontrol positif merupakan kelompok dengan pemberian CCL4 dan placebo berupa Na-CMC 1\%, sehingga menunjukkan kadar SOD yang paling rendah karena tidak mendapatkan asupan antioksidan, dan menujukkan kadar SOD yang paling rendah karena digunakan sebagai antioksidan utama dalam menangani radikal bebas.

Berdasarkan hasil uji statistik menunjukkan bahwa pada kelompok perlakuan memberikan pengaruh nyata $(p<0,05)$ terhadap kadar SOD pada kelompok kontrol positif. Sehingga perlu dilakukan uji lanjutan statistik untuk mengetahui dosis mana yang paling optimal dalam menaikkan kadar SOD serum darah tikus. Hasil uji lanjutan menujukkan bahwa pemberian ekstrak daun kecombrang dengan dosis 150 $\mathrm{mg} / \mathrm{KgBB}$ dan $200 \mathrm{mmg} / \mathrm{KgBB}$ lebih efektif dalam menaikkan SOD serum darah tikus dibandingkan dengan pemberian ekstrak daun kecombrang dengan dosis 100 $\mathrm{mg} / \mathrm{KgBB}(\mathrm{MD}>0,05)$, karena terbukti dengan hasil perhitungan kadar SOD dalam darah. Namun, pemberian ekstrak daun kecombrang dengan dosis $200 \mathrm{mg} / \mathrm{KgBB}$ tidak menunjukkan perbedaan nyata $(\mathrm{MD}<0,05)$ bila dibandingkan dengan pemberian ekstrak daun kecombrang dengan dosis $150 \mathrm{mg} / \mathrm{KgBB}$.

Penelitian yang dilakukan oleh Handayani, dkk. (2016) menyebutkan bahwa daun kecombrang mengandung antioksidan berupa flavonoid, fenolik, alkaloid dan 
saponin, dengan aktivitas antioksidan senilai IC50 30,65 $\mu \mathrm{g} / \mathrm{mL}$. Kandungan flavonoid dapat meminimalisir efek buruk radikal bebas dengan menghambat peroksidasi lipid melalui peningkatan antioksidan endogen seperti SOD (Irtanto, dkk., 2017). Aktivitas SOD berperan dalam melakukan pembersihan anion superoksida yang diubah menjadi hidrogen peroksidan dan menghilangkan toksisitas radikal bebas (Widyaningsih, dkk., 2015). Dengan demikian, kandungan antioksidan dalam ekstrak daun kecombrang mampu menetralisir radikal bebas dengan meningkatkan kadar SOD serum darah tikus yang diinduksi CCL4.

\section{KESIMPULAN}

Ekstrak cair daun kecombrang mampu meningkatkan kadar SOD dalam darah. Dosis pemberian ekstrak daun kecombrang yang paling optimal adalah dengan dosis 150 $\mathrm{mg} / \mathrm{KgBB}$._Dengan demikian, ekstrak cair daun kecombrang memiliki potensi untuk menetralisir radikal bebas dalam darah.

\section{DAFTAR PUSTAKA}

Ahmad, Aktsar Roskiana, dkk. 2017. "Penetapan Kadar Fenolik dan Flavonoid Total Ekstrak Metanol Buah dan Daun Patikala (Etlingera elatior (Jack) RM SM)." Pharmaceutical Sciences and Research (PSR). Vol. 2. No.1. Hlm. 1-10.

Handayani, Virsa, Aktsar Roskiana Ahmad, dan Miswati Sudir. 2016. "Uji Aktivitas Antioksidan Ekstrak Metanol Bunga dan Daun Patikala (Etlingera elatior (Jack) RM Sm) Menggunakan Metode DPPH." Pharmaceutical Sciences and Research (PSR). Vol. 1.No. 2. Hlm. 86-93.

Irtanto, Okky, Alex Pangkahila, dan IGM Aman. 2017 "Pemberian Ekstrak Floret Pisang Raja (Musa x paradisiaca) Mencegah Penurunan Kadar Superoksida Dismutase (SOD) pada Hati Mencit (Mus musculus) BALB/c dengan Aktivitas Fisik Berlebih." Jurnal Biomedik (JBM). Vol. 9. No. 3. Hlm. 166-171.

Kartika, Adinda Maya, Anang M. Legowo, dan S. Etza. 2017. "Pengaruh Penambahan Ekstrak Bunga Kecombrang (Etlingera etlatior) Terhadap Sifat Fisikokimia Gula Semut Kelapa."

Kurnia, Nita Hesti dan Titik Taufikurohmah. 2017. "Pengaruh Penambahan Nanosilver terhadap Aktivitas Antioksidan Nanogold dalam Meredam Radikal Bebas." UNNesa Journal of Chemistry. Vol. 6. No. 3.

Kurniawan, Deny, Arief Muliawan, dan Harlinda Kuspradini. 2017. "Efektivitas Ekastrak Buah Sonneratia alba terhadap Aktivitas Bakteri”. Jurna Harpodon Borneo. Vol. 10. No. 1.

Kusriani, Herni, dkk. 2017. "Aktivitas Antioksidan dan Sitotoksik serta Penetapan Kadar Senyawa Fenol Total Ekstrak Daun, Bunga dan Rimpang Kecombrang (Etlingera Elatior)." PHARMACY. Vol. 14. No. 1. Hlm. 51-63.

Lavi, S., Yang, E.H., Prasad, A., Mathew, V., Barsness, G.W.,Rihal, C.S., Lerman, L.O., dan Lerman, A. 2008. Oxidative Stress and Endothelial Function: The Interaction Between Coronary Endothelial Dysfunction, Local Oxidative Stress, and Endogenous Nitric Oxide in Humans. Hypertension; 51: 127-133.

Lestari, Garsinia dan Ira Puspa Kencana. 2008. Galeri Tanaman Hias Lanskap. Jakarta: Penebar Swadaya.

Murray, RK. Sel Darah merah dan sel darah putih. . Dalam: Murray RK, Granner DK, Rodwell VW, editor. Biokimia Harper. Jakarta: EGC; 2009. p.636-652. 
Safyudin, Subadrate. 2015. "Kadar Glutation (GSH) darah Kryawan SPBU di Palembang". Jurnal Kedokteran dan Kesehatan. Vol. 2 No. 3. Hlm. 277 - 281.

Winarsi, Hery. 2007. Antioksidan Alami dan Radikal Bebas. Yogyakarta: Kanisius.

Widyaningsih, Wahyu, Riza Sativa, dan Indra Primardiana. 2015. "Efek Antioksidan Ekstrak Etanol Ganggang Hijau (Ulva lactuca L.) Terhadap Kadar Melondialdehid (MDA) dan Aktivitas Enzim Superoksida Dismutase (SOD) Hepar Tikus yang Diinduksi CCL4". Media Farmasi. Vol. 12. No. 2. Hlm. 165 - 173. 